\title{
ANALISIS BEBAN KOGNITIF DALAM PEMECAHAN MASALAH MATEMATIKA
}

\author{
Aries Tejamukti \\ STKIP PGRI Tulungagung \\ Email: ariestejam@gmail.com
}

\begin{abstract}
Abstrak
Teori beban kognitif merupakan teori yang digunakan untuk mempelajari keterbatasan memori kerja dalam menerima informasi baru yang diperoleh. Tujuan penelitian untuk mendeskripsikan beban kognitif siswa yang muncul dalam pemecahan masalah matematika. Penelitian ini bersifat kualitatif deskriptif. Metode pengumpulan data yaitu dengan tes soal siswa, kuisioner beban kognitif, dan wawancara serta dilengkapi dengan dokumentasi. beban kognitif intrinsic yang muncul yaitu kurang menguasai konsep dan rumus dalam materi pelajaran selain itu kurang menguasai operasi bentuk aljabar. Beban kognitif exstraneous yang muncul yaitu kesulitan memahami gambar dalam soal. Sedangkan beban kognitif germane yang muncul yaitu siswa dapat mengingat kembali ingatan yang telah lalu dan dapat menerapkannya dalam soal tes.
\end{abstract}

Kata kunci: Teori Beban kognitif, Matematika, Pemecahan Masalah

\section{PENDAHULUAN}

Siswa dalam belajar berpusat pada kemampuan mental atau kognitifnya untuk dapat memahami yang dipelajarinya [1]. Kita ketahui bahwa di sekolah siswa harus menerima banyak informasi terutama dari mata pelajaran yang bermacam-macam dan harus dipahami dan dipelajari. Dalam pembelajaran matematika di sekolah banyak dijumpai siswa yang mengalami kesulitan dalam memahami pelajaran. Hal ini disebabkan matematika bersifat sangat abstrak, yakni berkenaan dengan konsep-konsep abstrak dan penalaran deduktif [2]. Oleh karena itu, dibutuhkan kemampuan kognitif yang lebih dalam pembelajaran matematika.

Beban kognitif merupakan usaha mental yang harus dilakukan dalam memori kerja untuk memproses informasi yang diterima pada selang waktu tertentu Plass dkk dalam [1]. Referensi [3] beban kognitif dapat dipandang sebagai tingkat energi mental yang dibutuhkan untuk memproses jumlah yang diberikan informasi (Cognitive load may be viewed as the level of 'mental energy' required to process a given amount of information).

Salah seorang ahli bernama John Sweller berkebangsaan Australia mengembangkan Teori beban kognitif dari studi pemecahan masalah pada akhir 1980-an yang berpendapat bahwa desain insrtuksional dapat digunakan untuk mengurangi beban kognitif siswa [4].
Pada penelitian selanjutnya Sweller berpendapat cognitive load theory deals with learning and problem solving difficulty that is artificial in that it can be manipulated by instructional design, teori beban kognitif berkaitan dengan kesulitan belajar dan pemecahan masalah yang bersifat buatan sehingga bisa dimanipulasi dengan desain instruksional [5].

Pada perkembangannya Teori Beban Kognitif dibagi menjadi 3 jenis yaitu: (a) beban kognitif intrinsic, (b) beban kognitif exstraneous, dan (c) beban kognitif germane [6]. Referensi [1] ketiga jenis beban kognitif diatas di definisikan sebagai berikut: (a) Beban kognitif intrinsic mengacu pada elemen interaktivitas dalam materi. (b) Beban kognitif exstraneous mengacu pada desain instruksional yang membebani siswa dalam belajar. (c) Beban kognitif germane mengacu pada usaha mental yang relevan dengan proses belajar. Dari definisi tersebut dapat kita simpulkan bahwa dalam beban kognitif intrinsic berkaitan dengan pemahaman siswa terhadap materi yang diberikan guru. Kemudian beban kognitif exstraneous berkaitan dengan strategi pembelajaran yang diberikan oleh guru kelas. Dan yang terakhir yaitu beban kognitif germane berkaitan dengan proses siswa dalam pemecahan masalah setelah mendapatkan pembelajaran. 
Mata pelajaran matematika siswa tidak hanya kesulitan dalam proses pembelajarannya melainkan terjadi juga dalam proses pemecahan masalah. Padahal kemampuan pemecahan masalah merupakan hal penting untuk dimiliki siswa seperti yang dipaparkan [2] pemecahan masalah melatih siswa untuk memproses data atau informasi.

Dalam melakukan aktivitas pemecahan masalah siswa berupaya memahami masalah yang sedang dihadapi, memikirkan rencana penyeleseiannya dan menerapkannya untuk menemukan solusi. Pada langkah terakhir dalam pemecahan masalah adalah memeriksa kembali hasil pemikiran dan solusi yang telah diperoleh. Hal ini sejalan dengan pendapat [7] yang terdiri dari “(1) Memahami masalah, (2) Membuat rencana penyelesaian, Menyelesaikan rencana penyelesaian, dan (4) Memeriksa kembali”. Pada pemaparan langkah-langkah pemecahan diatas dapat disimpulkan bahwa dalam pemecahan masalah dibutuhkan kemampuan kerja memori atau kemampuan kognitif siswa untuk menemukan solusi dari masalah yang dihadapi.

Bebarapa penelitian yang lalu mengenai pemecahan masalah matematika yang berkaitan dengan kemampuan kognisi diantaranya yang dilakukan oleh [8] dalam penelitiannya menyimpulkan bahwa fungsi kognisi adalah menyelesaikan permasalahan. Selain itu pada penelitian [9] menyimpulkan bahwa kognisi seseorang digunakan untuk membangun stategi pada pemecahan masalah. Dari penelitian tersebut dapat disimpulkan bahwa dalam pemecahan masalah membutuhkan kemampuan kognisi dalam diri seseorang/siswa.

Berdasarkan yang diuraikan di atas, maka peneliti berkeinginan untuk melakukan penelitian yang berjudul "Analisis Beban Kognitif Siswa Dalam Pemecahan Masalah Matematika". Berdasarkan judul penelitian diatas, maka fokus dalam penelitian ini adalah sebagai berikut: "Bagaimana beban kognitif siswa yang muncul dalam pemecahan masalah matematika pada siswa?". Sesuai dengan fokus masalah yang diteliti, maka tujuan dari penelitian ini adalah Untuk mendeskripsikan beban kognitif siswa yang muncul dalam pemecahan masalah matematika pada siswa.

\section{METODE}

Penelitian ini bertujuan untuk menganalisis beban kognitif siswa dalam pemecahan masalah matematika pada siswa yang dilakukan pada siswa kelas XI Akuntansi SMK Negeri 1 Bandung. Pendekatan yang digunakan adalah pendekatan kualitatif, karena dalam penelitian ini deskripsi yang disajikan tidak memaparkan hasil berupa angka atau nilai, namun lebih banyak memaparkan fenomena sosial atau objek secara alamiah. Prosesnya yaitu dengan mendiskripsikan, mencatat, mengguna-kan analisis dengan pendekatan induktif yang lebih menekankan proses dan makna, dan menginterprestasikan kejadian-kejadian yang sekarang ini ada atau terjadi. Dalam penelitian ini peneliti sebagai perencana, pengumpul data, penganalisis data, dan pelapor hasil penelitian. Selain itu dalam pendekatan kualitatif penelitian ini, peneliti menjadi instrumen kunci (utama) sehingga kehadiran dalam tempat penelitian sangat diperlukan.

Pada tahap awal, peneliti membuat perencanaan kegiatan awal sebelum pengumpulan data. Peneliti berperan sebagai pengumpul data yaitu mengumpulkan datadata dari hasil kuisioner/angket, hasil tes soal dan wawancara lapangan. Data yang sudah dikumpulkan selanjutnya akan dianalisis oleh peneliti. Sebagai penganalisis, peneliti bertugas membaca dan me-review data (dalam penelitian ini meninjau hasil kuisioner, lembar tes soal dan transkrip wawancara) untuk mendeteksi hal-hal yang terjadi dalam penelitian ini. Setelah semua data terkumpul peneliti akan membuat laporan dan menyampaikan hasil penelitian ini.

Pengumpulan data berdasarkan pada beban kognitif yang di alami siswa dalam pembelajaran matematika materi bangun datar. Teknik pengumpulan data yang digunakan untuk pengumpulan data dalam penelitian ini dilakukan dengan teknik: tes soal, kuisioner dan wawancara. Prosedur pengumpulan data 
yang dilakukan dalam penelitian ini adalah sebagai berikut:

1) Tes Soal

Referensi [10] merupakan metode yang sifatnya untuk mengevalusi hasil proses. Latihan soal dalam penelitian ini diberikan secara tertulis dan soal yang diberikan sebanyak 3 butir soal dengan materi bangun datar yang divalidasi oleh dua dosen matematika dan satu guru mata pelajaran matematika di sekolah.

\section{2) Kuisioner Beban Kognitif}

Kuisioner dalam penelitian ini digunakan untuk memproleh informasi dari responden tentang pribadinya atau hal-hal yang yang dirasakan maupun dialami dalam proses pembelajaran maupun tes soal. Dalam hal ini digunakan untuk mengelompokkan siswa berdasarkan beban kognitif ke dalam tiga kategori yaitu kategori: tingi, sedang, dan rendah. Kuisioner yang digunakan untuk mengukur beban kognitif pada penelitian ini menggunakan skala Semantik Differensial yang dibuat dalam bentuk tabel penskoran. Pada pemberian skor, menggunakan interval antara 0 sampai 10 dimana 0 berarti pertanyaan yang berada di dalam tabel tidak terjadi dan meningkat sampai 10 berarti pertanyaan yang di dalam tabel benarbenar terjadi. Dalam mengubah skor menjadi nilai menggunakan persamaan:

Nilai $=\frac{\sum \text { skor kuisioner/ angket siswa }}{\sum \text { skor maksimum }} \times 100$

Selanjutnya dari hasil nilai kuisioner siswa dikategorikan berdasarkan kriteria beban kognitif kedalam tiga kelompok yaitu tinggi, sedang dan rendah. Penentuan kategori ini berdasarkan pada hasil nilai kuisioner pada kuisioner beban kognitif.

Tabel 1. Pengelompokkan kriteria beban kognitif

\begin{tabular}{|c|c|}
\hline Kriteria pengelompokkan & Kriteria \\
\hline Nilai $>\bar{X}+S D$ & Tinggi \\
\hline $\bar{X}-S D \leq$ Nilai $\leq \bar{X}+S D$ & Sedang \\
\hline Nilai $<\bar{X}-S D$ & Rendah \\
\hline
\end{tabular}

3) Wawancara

Referensi [10] merupakan pertemuan dua orang untuk bertukar informasi dan ide melalui tanya jawab, sehingga dapat dikonstruksikan makna dalam suatu topik tertentu. Wawancara dilakukan untuk memperoleh informasi yang lebih mendalam yang tidak didapatkan peneliti dalam kuisioner maupun tes soal. Jenis wawancara yang digunakan dalam penelitian ini adalah wawancara semi terstruktur, karena peneliti hanya memerlukan guideline wawancara tanpa harus mempersiapkan daftar pertanyaan yang detail sehingga alur wawancara lebih mudah disesuaiakan. Hal ini akan memebuat proses wawancara berlangsung luwes, arahnya bisa lebih terbuka, percakapan tidak membuat jenuh kedua belah pihak, sehingga diperoleh informasi yang lebih kaya.

Analisis data adalah proses menyeleksi, menyederhanakan, memfokuskan, mengabstraksikan, mengorganisasikan data secara sistematis dan rasional sesuai dengan tujuan penelitian, serta mendeskripsikan data hasil penelitian itu dengan menggunakan tabel sebagai alat bantu untuk memudahkan dalam menginterpretasikan. Prosesnya terdapat upaya mendeskripsikan, mencatat, menggunakan analisis dengan pendekatan induktif yang lebih menekankan proses dan makna, dan menginterpretasikan kejadian-kejadian yang sekarang ini ada atau terjadi. TeknikAnalisis data pada penelitian ini mengikuti langkah Milles dan Huberman dalam [11] dilakukan melalui tiga tahap, yaitu:

(a) Reduksi Data, adalah proses merupakan proses pemilihan, pemusatan perhatian, pengabstraksian dan pentransformasian data kasar dari lapangan. Reduksi data dilakukan dengan mengkategorikan siswa berdasarkan tingkat beban kognitif siswa dari hasil kuisioner beban kognitif. Dari hasil kuisioner dan hasil tes soal nantinya akan diambil sampel siswa kemudian diwawancarai.

(b) Penyajian Data, adalah sekumpulan informasi tersusun yang memberi kemungkinan untuk menarik kesimpulan dan 
mengambil tindakan. Jadi penyajian data ialah suatu kumpulan informasi yang membantu kita memahami apa yang terjadi dan melakukan analisis lanjutan. Penyajian data dalam penelitian ini yaitu dari hasil kuisioner, menyajikan hasil tes soal siswa dan wawancara yang dilakukan terhadap siswa.

(c) Menarik Kesimpulan dan Verifikasi, adalah proses pengambilan intisari dari keseluruhan paparan atau penyajian data yang telah dideskripsikan untuk diformulasikan dalam bentuk kalimat yang singkat dan padat sebagai jawaban terhadap fokus penelitian yang telah ditentukan. Dalam penelitian ini, kesimpulan yang akan diambil adalah mengenai beban kognitif siswa yang muncul dalam pemecahan masalah matematika berdasarkan hasil data yang disajikan sebelumnya.

\section{HASIL DAN PEMBAHASAN}

Selama melakukan penelitian, peneliti mendapatkan beberapa data yang berhubungan dengan beban kognitif yang muncul dalam pemecahan masalah materi bangun datar. Data yang diperoleh berupa beban kognitif yang muncul dan juga penyebab beban kognitif yang muncul dalam pemecahan masalah matematika. Hasil yang diperoleh dalam penelitian ini adalah munculnya beban kognitif intrinsic, beban kognitif extraneous, dan beban kognitif germane dalam pemecahan masalah.

Kuisioner beban kognitif dalam penelitian ini digunakan untuk mengelompokkan subjek ke dalam tiga kelompok yaitu: tinggi, sedang, dan rendah. Angket diberikan kepada 37 siswa yang dilaksanakan setelah tes soal pemecahan masalah selesai dilakukan. Berdasarkan hasil analisis data dari kuisioner adalah sebagai berikut:

Tabel 2. Hasil kuisioner beban kognitif

\begin{tabular}{|c|c|c|c|}
\hline $\begin{array}{c}\text { Kriteria } \\
\text { Pengelompokan }\end{array}$ & Kriteria & $\begin{array}{c}\text { Jumlah } \\
\text { siswa }\end{array}$ & Presentase \\
\hline Nilai $\geq 62,7$ & Tinggi & 9 & $24 \%$ \\
\hline $\begin{array}{c}48,7 \leq \text { Nilai } \leq \\
62,7\end{array}$ & Sedang & 25 & $68 \%$ \\
\hline Nilai $\leq 48,7$ & Rendah & 3 & $8 \%$ \\
\hline
\end{tabular}

Subjek kategori tinggi (T) pada soal nomor 1 kesulitan pada rumus yang digunakan karena lupa sehingga mencontek hasil pekerjaan dari teman lainnya. Selain itu, Subjek T juga lupa dengan rumus layang-layang yang ditanyakan peneliti saat wawancara. Hal ini dianggap sangat memprihatinkan karena rumus-rumus bangun datar sudah diajarkan saat duduk di bangku SMP (Sekolah Menengah Pertama). Hal ini pula yang menyebabkan beban kognitif intrinsic muncul karena lupa dengan rumus yang digunakan dalam mengerjakan bangun datar tersebut. sebagaimana pendapat Kalyuga dalam [1]bahwa beban kognitif intrinsic ditentukan oleh interaksi antar unsur penting dari informasi yang digunakan untuk memahami materi.

Pada soal nomor 2 beban kognitif intrinsic juga muncul ketika subjek kategori tinggi (T) kurang menguasai konsep operasi aljabar. Hal ini berdasarkan hasil wawancara yang dilakukan peneliti dengan memberi pertanyaan jika lebar pada soal diganti dengan $(2 x+1)$. Subjek $\mathrm{T}$ terlihat kebingungan dan tidak dapat menemukan hasilnya. Hal ini juga sangat memprihatinkan karena operasi aljabar juga sudah diajarkan di SMP (Sekolah Menengah Pertama). Kemampuan siswa dalam melakukan operasi aljabar merupakan beban kognitif intrinsic karena merupakan elemen yang sudah dipelajari dan berhubungan dengan elemen yang dipelajari saat ini Kalyuga dalam [1].

Pada soal nomor 3, subjek kategori tinggi, sedang dan rendah mengalami kesulitan dalam menentukan keliling bangun bentuk tidak beraturan. Hal ini karena ketiga subjek kurang menguasai konsep rumus mencari keliling bangun tidak beraturan. Berdasarkan hal tersebut ketiga subjek mengalami beban kognitif intrinsic yaitu kurang menguasai konsep rumus mencari keliling bangun tidak beraturan. Beban kognitif intrinsic merupakan interaksi antar elemen yang harus diproses secara bersama-sama antar unsur-unsur dalam materi Lin dan Lin dalam [1]. Sehingga kurangnya menguasai konsep rumus mencari keliling bangun bentuk tidak beraturan juga 
dapat mengakibatkan beban kognitif intrinsic dalam pemecahan masalah.

Beban kognitif exstraneous yang muncul yaitu kebingungan subjek $\mathrm{T}$ pada gambar di soal. Hal ini dapat dikatakan bahwa kurangnya informasi dari soal maupun kurang jelasnya gambar dapat menimbulkan beban kognitif exstraneous. Temuan ini sejalan dengan pendapat Sweller dkk dalam [1] bahwa Beban kognitif exstraneous merupakan beban yang berasal dari desain instruksional yang membuat semakin membebani siswa dalam belajar. Beban kognitif exstraneous ini muncul dalam soal nomor 1 .

Selain itu, subjek kategori sedang (S) juga mengalami kesulitan dalam memahami gambar pada awal mengerjakan. Akan tetapi kesulitan tersebut dapat diatasi dengan ingatan masa lalu tentang gambar tersebut. Gambar pada soal tersebut dijumpai subjek ketika berada di rumah tetangga rumahnya. Kesulitan subjek dalam memahami gambar karena kurang jelasnya gambar merupakan beban kognitif exstraneous. Akan tetapi beban kognitif exstraneous dapat dikurang dengan adanya beban kognitif germane yakni usaha yang dilakukan subjek dengan mengingat ingatan masa lalu tentang gambar pada soal tersebut. Hal ini sebagaimana di ungkapkan Cooper dalam [12] bahwa beban kognitif germane berperan sebagai pengorganisasi, pengkonstruksi, pengkode, pengelaborasian atau pengintegrasian materi yang sedang dipelajari sebagai pengetahuan yang tersimpan di memori jangka panjang.

Subjek kategori rendah (S) pada soal nomor 1 tidak terlalu mengalami kesulitan dalam menyelesaikan soal pemecahan masalah. subjek juga terbantu dengan ingatan masa lalu yang pernah ditemui dengan apa yang tanyakan soal. Hampir sama dengan dengan subjek kategori sedang sebelumnya akan tetapi subjek kategori rendah ini tanpa mengalami kesulitan sebelumnya dalan memahami gambar dalam soal. Usaha yang dilakukan subjek mengakibatkan beban kognitif germane dimana subjek mengingat kembali ingatan yang pernah ditemui dan menerapkannya dalam menyelesaikan soal. Beban kognitif germane (Germane Cognitive load) diperlukan untuk mengkonstruksi dan menyimpan skema ke memory jangka panjang [13].

\section{SIMPULAN DAN SARAN}

Bedasarkan hasil temuan dan pembahasan yang telah diuraikan, subyek kategori tinggi, sedang dan rendah beban kognitif yang muncul:

Beban kognitif intrinsic yaitu: (a)kurangnya menguasai rumus-rumus bangun datar (b) konsep operasi aljabar yang kurang (c) kurang pemahaman dan menguasai konsep mencari keliling bangun datar bentuk tidak beraturan. Berdasarkan hal tersebut peneliti menyimpulkan beban kognitif yang muncul karena ketidak pahaman siswa dengan konsep matematika.

Beban kognitif exstraneous yang muncul yaitu kesulitan membayangkan gambar pada bentuk aslinya serta kerumitan gambar dalam soal. Kesulitan ini dikarenakan gambar yang kurang jelas sehingga siswa tidak dapat memahaminya. Berdasarkan hal tersebut peneliti menyimpulkan bahwa beban kognitif muncul karena desain gambar dalam tes soal pemecahan masalah yang kurang jelas.

Beban kognitif germane yang muncul yaitu usaha atau upaya siswa dalam mengingat kembali ingatan yang lalu tentang bentuk gambar pada benda aslinya dan dapat menerapkan dalam soal. Berdasarkan hal tersebut peneliti menyimpulkan bahwa beban kognitif muncul ketia usaha atau upaya siswa yang relevan untuk mengerjakan tes soal atau latihan soal dalam pemecahan masalah dengan mengingat kembali ingatan masa lalu.

Berdasarkan hasil temuan penelitian dan kesimpulan yang diperoleh serta keterbatasan penelitian ini, maka peneliti menyarankan:

Penelitian ini masih menggunakan materi bangun datar dalam memecahkan masalah matematika jadi untuk penelitian selanjutnya diharapkan menggunakan materi lain yang lebih memungkinkan menggali beban kognitif yang muncul.

Dalam penelitian ini kategori beban kognitif tinggi sedang maupun rendah hanya digunakan untuk menentukan subjek yang 
dipilih. Untuk penelitian selanjutnya, peneliti menyarankan untuk lebih merinci beban kognitif yang muncul berdasarkan kategori tinggi, sedang dan rendah. Sehingga temuan penelitian tentang beban kognitif akan lebih mendalam.

\section{REFERENSI}

Yohanes, B. 2016. Beban Kognitif Siswa Dalam Pembelajaran . Jurnal Pendidikan: Teori, Penelitian, dan Pengembangan,. Vol. 6.2 (II). 187-195

Hudojo, H. (2005). Perngembangan Kurikulum dan Pembelajaran Matematika. Malang: Universitas Negeri Malang.

Cooper, G. (1988). Cognitive load theory as an aid for instructional design. Australian Journal of Educational Technology. Vol. 6,2 (II)

Sweller, J. (1988). Cognitive Load During Problem Solving: Effects on Learning, 285, 257-285. (online).

Sweller, J. (1994). Cognitive load theory, learning difficulty, and instructional design. Learning and Instruction, 4(4), 295-312. (online)

Plass, L. J., Moreno, R. \& Brunken, R. 2010. Cognitive Load Theory. New York: Cambridge University Press. (online).
Polya, G. 1973. How To Solve It. New Jersey: Princeton University Press (online)

Chairani, Zahra. 2015. Perilaku Metakognisi dalam Pemecahan Masalah Matematika. Jurnal Pendidikan Matematika (online), Vol. 1, No. 3(III)

Romli, M. (2000). Strategi Membangun Metakognisi Siswa Sma Dalam Pemecahan Masalah Matematika. (Online)

Listiawan, T., \& Baskoro, W. W. (2015). Analisis Technological Content Knowledge (TCK ) Calon Guru Matematika Dalam Menggunakan Perangkat Lunak Geometri Dinamis, Seminar Nasional Matematika Dan Pendidikan Matematika UNY, 827-834.

Sugiyono. 2015. Memahami Penelitian Kualitatif. Bandung: CV. Alfabeta

Kamaruddin. (2016). Penerapan Pembelajaran Statistika 2 Mengacu Pada Teori Beban Kognitif Pada Mahasiswa Matematika Universitas Kaltara Tahun Ajaran 2015 / 2016, 95-100

Kirschner, Paul. A. 2012. Cognitive Load Theory: Implications of Cognitive Load Theory On The Design Of Learning. Learning and Instruction. 12. 1-10 